\title{
Petrogenesis of the Palaeoarchean Keonjhar Granite, Singhbhum Craton, India: product of crustal reworking or subduction?
}

\author{
Ajay Dev Asokan ${ }^{1,2}$, Kumar Krishna ${ }^{1}$, R. Elangovan ${ }^{1}$ and M. Ram Mohan ${ }^{1, *}$ \\ ${ }^{1}$ CSIR-National Geophysical Research Institute, Hyderabad 500 007, India \\ ${ }^{2}$ Academy of Scientific and Innovative Research, CSIR-National Geophysical Research Institute, Hyderabad 500 007, India
}

The early Archean represents an important eon in the evolution of the earth's continental crust and could provide insights into the nature of geodynamic processes that operated during that period. The Singhbhum Craton from the Indian Shield is the only major archive of Palaeo-Mesoarchean geological processes. The Palaeoarchean granitoids from the Keonjhar area of Singhbhum Craton are potassic granites and granodiorites of calc-alkaline affinity. Their age and elemental concentrations resemble the low $\mathrm{Al}_{2} \mathrm{O}_{3}$ granites reported from the Eastern Pilbara Craton of Australia. The geochemical systematics of these granitoids suggests their derivation due to crustal reworking involving partial melting of a tonalitic source, possibly older metamorphic tonalitic gneiss (OMTG). The OMTG could have been derived due to the melting of an enriched basaltic source at the base of an oceanic plateau. In the second stage, the resultant underplating at crustal levels caused the reworking that led to intracrustal melting and differentiation of OMTG to form potassic granites, similar to that of Keonjhar pluton. Consolidating the evidences from the available geochemical and isotopic studies with our own data and correlating them with the geophysical evidences, we interpret that the Keonjhar granitoids are the product of intracrustal melting in an oceanic plateau setting.

Keywords: Geodynamic processes, granitoids, intracrustal melting, petrogenesis.

AROUND $60 \%$ of the present-day exposed continental crust is estimated to have formed by $3 \mathrm{Ga}$; however, the rate of crust generation and geodynamic processes responsible for crustal growth remains largely debated ${ }^{1,2}$. The initiation of plate tectonics is a matter of contention, though it has been reported as early as from $3.8 \mathrm{Ga}$ from the Isua greenstone belt ${ }^{3-5}$. Multiple evidences for the operation of plate tectonics, at least from $3.1 \mathrm{Ga}$ are inferred from field evidences, oxygen and hafnium isotopic systematics, inclusions in eclogites and diamonds, and geothermal gradients calculated from high-grade

*For correspondence. (e-mail: rammohan@ngri.res.in) metamorphic rocks ${ }^{1,6-9}$. However, the idea that continental crust generation is mainly through subduction-accretion processes has been questioned by preservation rates at subduction zones ${ }^{10,11}$.

The higher mantle convection rates and resultant plume activity during the Archean are assumed to be due to higher mantle temperatures ${ }^{12}$. The mantle plumes initiated oceanic plateau formation and their subsequent reworking and differentiation led to continental crust formation without subduction ${ }^{13,14}$. Another popular model proposed to explain that the early to mid-Archean geodynamics is the stagnant lid hypothesis, wherein the plumes triggered by mantle convections below a stagnant cold lid resulted in the formation of basalts and komatiites ${ }^{15}$.

Most of the available information on the Palaeoarchean geological processes is mainly based on studies from Pilbara and Kapvaal cratons $8,14,16$. Due to the spatial abundance and economic importance of greenstone belts, Neoarchean cratons with voluminous tonalite-trondhjemitegranodiorite (TTGs) have been widely studied for understanding the Archean geodynamics, crustal growth and mineralization. Apart from TTGs, potassic granites form a major component of Neoarchean cratons, and are divided into sanukitoids and biotite- and two-mica granites whose genesis is linked to subduction-collision processes ${ }^{17}$. The potassic granites from Palaeoarchean cratons have received less attention and their petrogenesis is attributed to intracrustal melting of a thickened crust ${ }^{16,18}$.

The Indian subcontinent is an amalgamation of various Archean cratons. The Singhbhum Craton with its abundant Palaeoarchean lithounits can provide a window to study the early Archean crust generation processes. In this study, we present petrogenetic evolution of potassic granites from the Keonjhar area of Singhbhum Craton. Based on our data, we propose a tectonic model unlikely to be linked to subduction. Also, we draw evidences from existing data/models that explain the Palaeoarchean evolution of the Singhbhum Craton.

\section{Regional geology}

The Singhbhum Craton (Figure 1), spread over $40,000 \mathrm{sq} . \mathrm{km}$ is a major archive of Palaeo to Mesoarchean 
processes in the Indian shield. Its boundaries are demarcated by the Singhbhum mobile belt in the north, Mahanadi rift in the southwest and alluvium from the Bengal basin in the east. The oldest lithounit in this craton is considered to be the Older Metamorphic Group (OMG) followed by granitoid magmatism, i.e. Older Metamorphic Tonalitic Gneiss (OMTG) and Singhbhum Granite (SG) ${ }^{19,20}$. OMG constitutes pelitic schists, arenites, calc arenites, calc shists, and ortho and para amphibolites that have undergone amphibolite facies metamorphism ${ }^{19-21}$. TTGs are the major components of OMTG with minor quartz diorite and quartz monzonite ${ }^{19}$. Singhbhum granite batholithic complex forms the major part of the craton and covers $10,000 \mathrm{sq}$. $\mathrm{km}$. The composition of SG varies from biotite granodiorite grading to monzogranite, and rarely to trondhjemite. OMG and OMTG occur as enclaves within $\mathrm{SG}^{19}$.

The greenstone belts partially bordering SG are collectively called Iron Ore Group (IOG), occurring as three

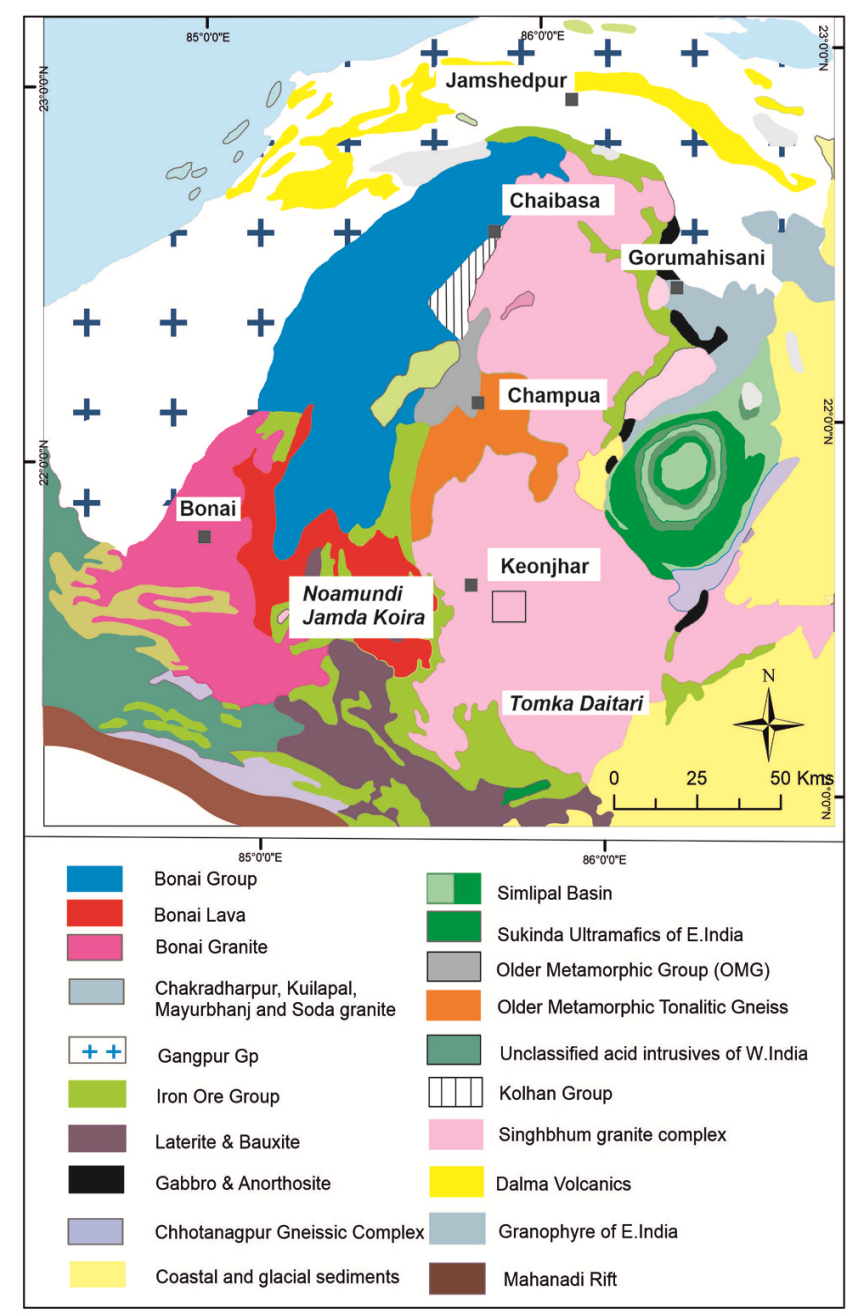

Figure 1. Simplified geological map of the Singhbhum Craton with major lithounits, modified after Saha ${ }^{19}$. Sampling locations are close to Keonjhar and shown within rectangular boxes. different basins made of supracrustals that have undergone low-grade metamorphism ${ }^{19}$. OMG is considered to be a part of the IOG supracrustals that have undergone high-grade metamorphism ${ }^{22}$. Noamundi-Tomka-Daiteri basin located in the south, Gorumahisani-Badampahar basin along the northeast and Jamda Koira basin in the west are the three IOG basins (Figure 1) ${ }^{19}$. The southern IOG basin has been assigned an age of $3.5 \mathrm{Ga}$ based on zircon $\mathrm{U}-\mathrm{Pb}$ dating of dacitic tuff that forms part of a bimodal suite ${ }^{23,24}$.

The Singhbhum Granite is a collection of 12 individual plutons and has been divided into three phases based on field, structural, mineralogical and geochemical characteristics $^{19}$. The three-phase classification validity has been questioned by recent workers, who have established that only two magmatic events dated at $\sim 3.45$ TTG and $\sim 3.32$ granitoids have occurred ${ }^{25-27}$. Zircons from OMG have a crystallization age of $\sim 3.55 \mathrm{Ga}$ (ref. 21). Many workers obtained $\sim 3.45$ Ga zircons from OMTG rocks ${ }^{26-28}$. SG is emplaced at $\sim 3.3 \mathrm{Ga}$ and older ages are assumed to be from inherited zircon xenocrysts from OMTG ${ }^{25-27,29}$. Hadean zircon xenocrysts were obtained from OMTG and river sediments ${ }^{30,31}$. SG is cut across by Neoarchean $(2.76 \mathrm{Ga})$ and Early Proterozoic $(1.76 \mathrm{Ga})$ dyke swarms of two different trends, known as Newer Dolerite Dykes $(\mathrm{NDDs})^{32,33}$. K-feldspar megacrysts are characteristic of the Keonjhargarh-Bhaunra unit ${ }^{19,25}$ and have been assigned an emplacement age of $\sim 3.3 \mathrm{Ga}$ (refs 25, 26 and 29).

\section{Field relationships}

Keonjhar granites form part of the second phase of granitoid magmatism in the earlier classification scheme (Figure 1$)^{19}$. Based on the megascopic features and mineral abundances, granitoids of Keonjhar region can be divided into two types: (i) porphyritic (K-feldspar megacrystic) granitoids (Figure $2 a$ ), and (ii) non-porphyritic granites (Figure $2 b$ and $c$ ). NDDs are seen throughout the area with NNE-WSW trend and N-S trend, cross-cutting the granitoids at numerous places. The weathered contact between the porphyritic and non-porphyritic granitoid types was observed, though its nature is not clear (Figure $2 d$ ). The studied granitoids have not undergone any major deformation at the outcrop level. Eleven samples were collected from fresh-looking surfaces devoid of visible veins and baked feldspar. The samples showed difference in mafic mineral abundance megascopically, and plagioclase had slight greenish tint at few places, indicating epidotization. Samples were collected from outcrops located around $10 \mathrm{~km}$ from Keonjhar town in the southeast direction.

\section{Petrography}

The primary features as observed megascopically in the two granitoid variants are reflected in petrography. The 

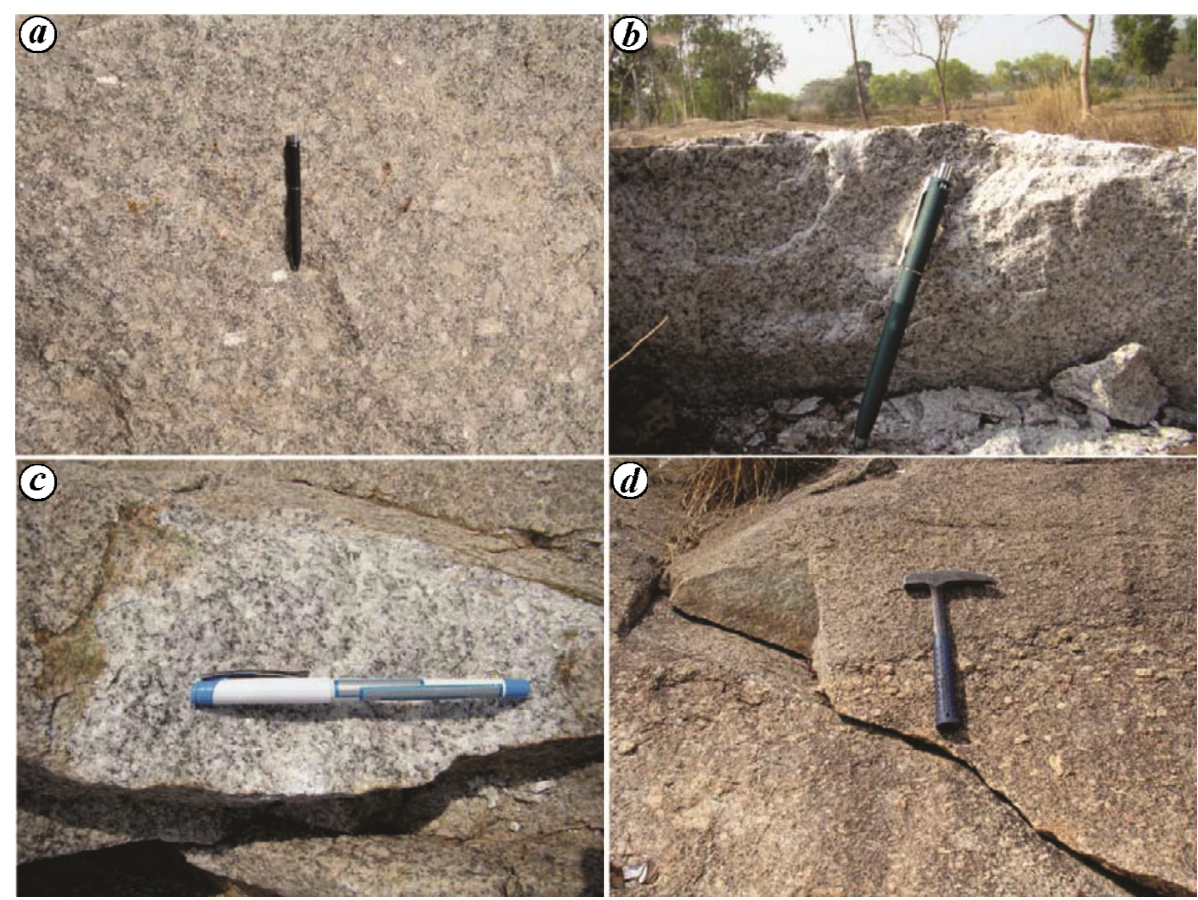

Figure 2. Representative field photographs of Keonjhar granitoids. $\boldsymbol{a}$, K-feldspar megacryst porphyritic granitoid. $\boldsymbol{b}, \boldsymbol{c}$, Non-porphyritic granitoid. $\boldsymbol{d}$, Weathered contact between porphyritic and non-porphyritic granitoids.

K-feldspar megacryst containing porphyritic granitoids displays granular interlocking texture with K-feldspar, plagioclase and quartz as major minerals (Figure $3 a$ and $b)$. Biotite, chlorite, allanite, epidote, muscovite, zircon and apatite are accessory minerals. The plagioclase is sub-hedral to euhedral and is poikilitically enclosed in large perthitic feldspar grains (Figure $3 a$ ). Some plagioclase grains are zoned and also have resorbed boundary, and have undergone extensive sericitization and saussuritization (Figure $3 a-d$ ). Quartz is the only mineral that displays internal deformation and sub-grain formation. Chlorite occurs as secondary mineral with muscovite and biotite undergoing alteration along their cleavage planes. The non-porphyritic granitoids have the same major minerals, but with higher plagioclase abundance than $\mathrm{K}$-feldspar, and have equigranular texture (Figure $3 c$ and d). Apart from minor hornblende, other accessory phases remain largely same. Large K-feldspar crystals are absent, but both microcline and orthoclase are present. Hornblende has undergone chloritization. Abundance of primary mafic magmatic minerals is noticeably low in both the granitoid varieties.

\section{Analytical techniques}

Eleven representative samples of both granitoid types were reduced into chips manually. Fragments with minute veins or weathering rinds were carefully removed. Further reduction was done using jaw crusher and agate mortar to obtain fine powder ( 250 mesh). Major elements were analysed using XRF (Phillips MAGIX PRO Model
2440) at CSIR-National Geophysical Research Institute (NGRI), Hyderabad by preparing pressed sample pellets $^{34}$. About 1-2 g of fine powder was spread over collapsible aluminium cups filled with boric acid and pressed at 25 tonnes for $30 \mathrm{sec}$ in a hydraulic pellet pressing machine. For trace and rare earth element (REE) analyses, closed digestion technique was followed; the analyses were carried out using the HR-ICP-MS $(\mathrm{Nu}$ instruments, ATTOM High Resolution Inductively Coupled Plasma Mass Spectrometer, UK) facility at CSIR-NGRI. The sample preparation procedure is briefly discussed here. First, $10 \mathrm{ml}$ of the acid mixture containing $\mathrm{HF}$ and $\mathrm{HNO}_{3}$ in $7: 3$ proportion was added to $0.5 \mathrm{~g}$ of sample taken in Savillex vials, and heated for $48 \mathrm{~h}$ at $150^{\circ} \mathrm{C}$, keeping the lids closed. Later, 1-2 drops of perchloric acid $\left(\mathrm{HClO}_{4}\right)$ was added and the sample solutions were dried to form a solid residue. To dissolve this residue, $20 \mathrm{ml}$ of acid mixture containing $\mathrm{HNO}_{3}$ and Millipore water in $1: 1$ proportion was added and the samples were heated at $80^{\circ} \mathrm{C}$ for $1 \mathrm{~h}$. Next, $5 \mathrm{ml}$ of $1 \mathrm{ppm}$ rhodium was used as the internal standard and sample solutions were diluted to $250 \mathrm{ml}$ using Millipore water. To attain the optimal total dissolved solids (TDS), $5 \mathrm{ml}$ of this diluted solution was further diluted to $50 \mathrm{ml}$ before being analysed for trace and REE. G-2 (United States Geological Survey) and JG-1A (Japan Geological Survey) were the standards used for calibration and the data obtained were with RSD $<5 \%$ for all the analysed elements. Details on sample preparation, operating parameters of the instrument, data processing and quality are provided elsewhere ${ }^{35}$.

CURRENT SCIENCE, VOL. 118, NO. 6, 25 MARCH 2020 

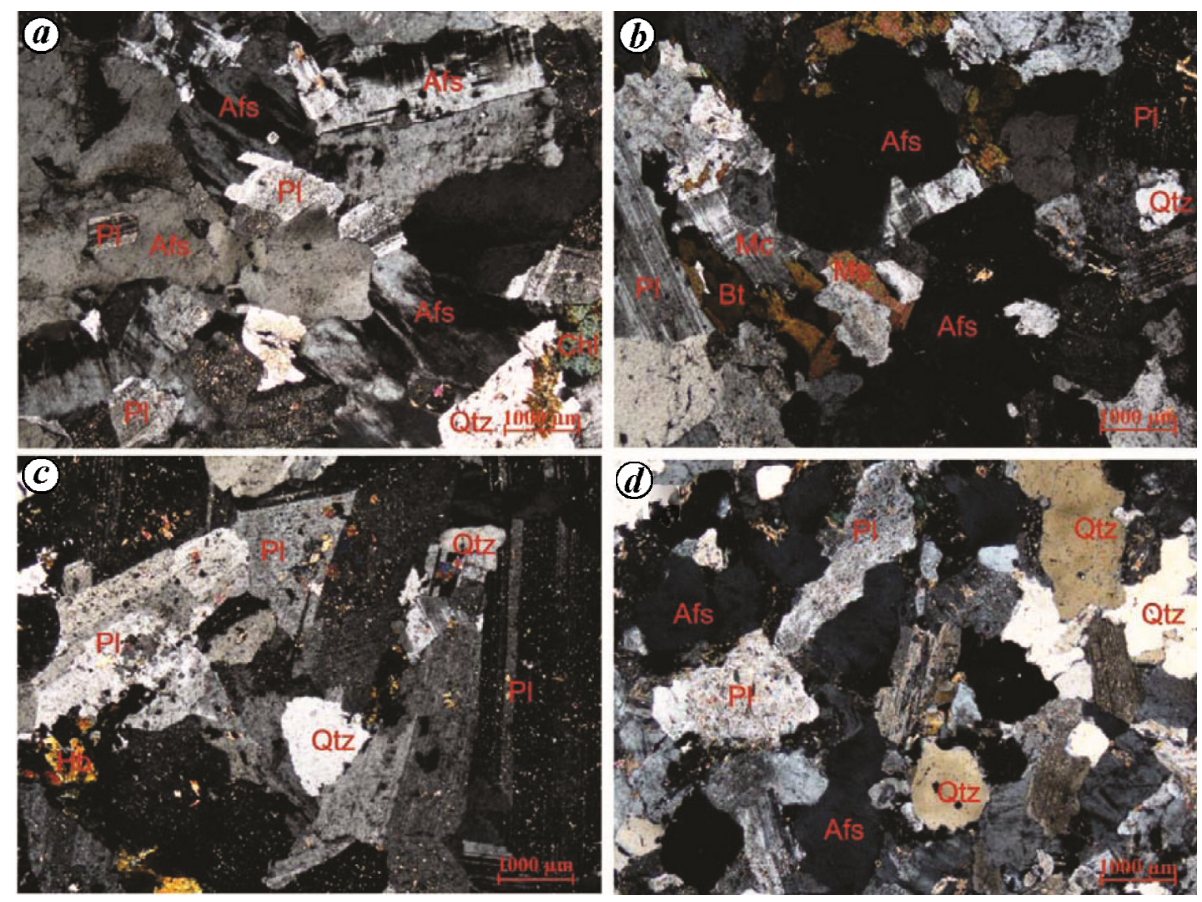

Figure 3. Photomicrographs of Keonjhar granitoids showing mineral assemblage and textural features. $\boldsymbol{a}, \boldsymbol{b}$, Porphyritic granitoids. $\boldsymbol{c}, \boldsymbol{d}$, Non-porphyritic granitoids.

\section{Geochemistry}

The geochemical data for Keonjhar granitoids is presented in Table 1, along with important elemental ratios. On the basis of normative mineralogy and geochemistry, the porphyritic granitoids are identified as monzogranites and non-porphyritic granitoids as granodiorites (Figure $4 a$ ). Samples with high potassium content were checked for post-crystallization alterations like K-metasomatism and found to be unaltered ${ }^{36}$.

The studied samples have $\mathrm{SiO}_{2}$ values ranging from 72 to $74 \mathrm{wt} \%$ and are potassic $\left(\mathrm{K}_{2} \mathrm{O} / \mathrm{Na}_{2} \mathrm{O}>0.5\right)$, with monzogranites being more potassic than the granodiorites (Figure $4 c$ ). In the alumina saturation index diagram ${ }^{37}$, the granitoids are mildly metaluminous to peraluminous (Figure $4 d$ ). All the samples have low concentration of ferromagnesian elements such as $\mathrm{TiO}_{2}(<0.2 \mathrm{wt} \%)$, $\mathrm{MgO}(<0.3 \mathrm{wt} \%)$ and $\mathrm{Fe}_{2} \mathrm{O}_{3}(<2 \mathrm{wt} \%)$. These are calcalkaline in nature with high $\mathrm{Zr} / \mathrm{Y}$ values $(>8.6)$ (Table 1) and this has been further validated by the $\mathrm{K}-\mathrm{Ca}-\mathrm{Na}$ plot to check whether they have any trondhjemitic affinity ${ }^{38}$ (Figure $4 b$ ). The Mg number is $<40$, ruling out the possibility of peridotite assimilation during their emplacement ${ }^{39}$. All the samples have transition elements in low concentration ( $\mathrm{Ni} 3-6 \mathrm{ppm}, \mathrm{Cr} 11-135 \mathrm{ppm}$ and $\mathrm{V} \mathrm{1-4} \mathrm{ppm),}$ variable large-ion lithophile elements (LILEs) and comparatively lower high-field-strength elements (HFSEs) composition ( $\mathrm{Nb} 5-33 \mathrm{ppm}, \mathrm{Ta}<2 \mathrm{ppm}, \mathrm{Zr} 120$ 508 ppm, Y 5-14 ppm and Hf 4-11 ppm). On the chondrite normalized REE diagram ${ }^{40}$, samples exhibit strongly fractionated pattern with enriched LREE, flat HREE and negative Europium anomaly (Figure $5 a$ ). Granodiorites are relatively more fractionated with avg. $(\mathrm{La} / \mathrm{Yb})_{\mathrm{N}}=58$ compared to the monzogranites with avg $(\mathrm{La} / \mathrm{Yb})_{\mathrm{N}}=27$. The monzogranites are slightly enriched in their REEs content which could be due to their late-stage crystallization, as evident by the formation of K-feldspar megacrysts. A granodiorite sample is noted for its positive Europium anomaly, higher $\mathrm{Sr}(>300 \mathrm{ppm})$ and low $\mathrm{Y}$ $(5 \mathrm{ppm})$ concentration. The primitive mantle normalized multielemental variation diagram exhibits relative enrichment of LILE and HFSE depletion (Figure $5 b$ ). Such patterns are common for rocks formed in arc (continental or island) settings.

\section{Discussion}

\section{Petrogenesis of Keonjhar granites from the Singhbum Craton}

The major elemental composition of these samples is $\mathrm{Al}_{2} \mathrm{O}_{3} \quad(12-15 \mathrm{wt} \%), \mathrm{Fe}_{2} \mathrm{O}_{3} \quad(0.8-3 \mathrm{wt} \%), \quad \mathrm{MgO}(0.1-$ $0.5 \mathrm{wt} \%), \mathrm{CaO}(0.5-2 \mathrm{wt} \%)$, and concentration of trace elements like Rb (100-250 ppm), Sr (50-250 ppm) and Th (4-15 ppm), is similar to the calc-alkaline 3.32 $3.28 \mathrm{Ga}$ low $\mathrm{Al}_{2} \mathrm{O}_{3}$-type granites reported from the Eastern Pilbara Craton ${ }^{41,42}$. The metaluminous to mildly peraluminous nature indicates low sedimentary input in the genesis of these granitoids (Figure $4 d$ ). The geochemistry of the Keonjhar granites exhibits calc-alkaline affinity 
Table 1. Major and trace element compositions of Keonjhar granitoids along with key geochemical ratios

\begin{tabular}{|c|c|c|c|c|c|c|c|c|c|c|c|}
\hline Sample & $\begin{array}{l}\text { Non- } \\
\text { porphyritic } \\
\text { SG18-5 }\end{array}$ & $\begin{array}{c}\text { Non- } \\
\text { porphyritic } \\
\text { SG18/17 }\end{array}$ & $\begin{array}{c}\text { Non- } \\
\text { porphyritic } \\
\text { SG18/18 }\end{array}$ & $\begin{array}{c}\text { Non- } \\
\text { porphyritic } \\
\text { KDJR-18 }\end{array}$ & $\begin{array}{c}\text { Non- } \\
\text { porphyritic } \\
\text { KDJR-16 }\end{array}$ & $\begin{array}{l}\text { Porphyritic } \\
\text { KDJR-12 }\end{array}$ & $\begin{array}{c}\text { Porphyritic } \\
\text { SG18-4 }\end{array}$ & $\begin{array}{c}\text { Porphyritic } \\
\text { SG18-6 }\end{array}$ & $\begin{array}{c}\text { Porphyritic } \\
\text { KDJR-7 }\end{array}$ & $\begin{array}{c}\text { Porphyritic } \\
\text { SG18-2 }\end{array}$ & $\begin{array}{c}\text { Porphyritic } \\
\text { KDJR-1 }\end{array}$ \\
\hline $\mathrm{SiO}_{2}(\mathrm{wt} \%)$ & 72.75 & 72.79 & 71.76 & 72.46 & 72.62 & 74.20 & 71.94 & 72.87 & 71.99 & 72.00 & 71.80 \\
\hline $\mathrm{Al}_{2} \mathrm{O}_{3}$ & 13.89 & 14.13 & 14.72 & 14.33 & 14.46 & 13.85 & 14.13 & 13.85 & 14.53 & 14.90 & 14.66 \\
\hline $\mathrm{Fe}_{2} \mathrm{O}_{3}$ & 1.74 & 1.50 & 1.47 & 1.73 & 1.44 & 1.35 & 1.90 & 1.67 & 1.68 & 2.17 & 2.04 \\
\hline $\mathrm{MnO}$ & 0.02 & 0.03 & 0.03 & 0.03 & 0.03 & 0.02 & 0.03 & 0.02 & 0.04 & 0.03 & 0.02 \\
\hline $\mathrm{CaO}$ & 1.51 & 1.23 & 1.36 & 1.13 & 0.78 & 0.95 & 1.10 & 1.23 & 1.22 & 1.17 & 0.97 \\
\hline $\mathrm{Na}_{2} \mathrm{O}$ & 5.10 & 4.81 & 4.85 & 4.83 & 4.77 & 4.77 & 4.77 & 4.35 & 4.33 & 4.25 & 3.98 \\
\hline $\mathrm{K}_{2} \mathrm{O}$ & 2.69 & 3.35 & 3.51 & 3.81 & 3.95 & 3.83 & 3.91 & 3.87 & 4.29 & 4.34 & 5.17 \\
\hline $\mathrm{TiO}_{2}$ & 0.19 & 0.14 & 0.15 & 0.18 & 0.13 & 0.10 & 0.20 & 0.22 & 0.16 & 0.22 & 0.21 \\
\hline $\mathrm{P}_{2} \mathrm{O}_{5}$ & 0.05 & 0.04 & 0.04 & 0.05 & 0.04 & 0.03 & 0.06 & 0.06 & 0.04 & 0.06 & 0.06 \\
\hline LOI & 0.72 & 0.65 & 0.7 & 0.58 & 0.57 & 0.68 & 0.78 & 0.74 & 0.89 & 0.8 & 0.69 \\
\hline Sum & 98.93 & 98.92 & 98.86 & 99.38 & 99.07 & 99.88 & 99.06 & 99.08 & 99.37 & 100.15 & 99.79 \\
\hline $\mathrm{K}_{2} \mathrm{O} / \mathrm{Na}_{2} \mathrm{O}$ & 0.53 & 0.70 & 0.72 & 0.79 & 0.83 & 0.80 & 0.82 & 0.89 & 0.99 & 1.02 & 1.30 \\
\hline $\mathrm{A} / \mathrm{CNK}$ & 0.99 & 1.03 & 1.03 & 1.01 & 1.07 & 1.01 & 1.00 & 1.02 & 1.04 & 1.08 & 1.05 \\
\hline $\mathrm{A} / \mathrm{NK}$ & 1.23 & 1.23 & 1.25 & 1.19 & 1.19 & 1.16 & 1.17 & 1.22 & 1.23 & 1.27 & 1.21 \\
\hline $\mathrm{Ti}(\mathrm{ppm})$ & 1129 & 821 & 882 & 1091 & 766 & 592 & 1227 & 1329 & 938 & 1299 & 1274 \\
\hline $\mathrm{P}$ & 215 & 154 & 189 & 219 & 167 & 127 & 246 & 255 & 185 & 260 & 268 \\
\hline $\mathrm{Cr}$ & 113 & 79.83 & 78.57 & 15.66 & 17.27 & 11.81 & 123 & 118 & 14.62 & 135 & 16.75 \\
\hline $\mathrm{Co}$ & 2.87 & 2.11 & 2.03 & 2.23 & 1.94 & 10.77 & 3.19 & 3.22 & 2.50 & 3.67 & 3.39 \\
\hline $\mathrm{Ni}$ & 6.09 & 6.41 & 5.93 & 4.12 & 2.81 & 5.68 & 5.82 & 6.19 & 5.82 & 7.27 & 7.29 \\
\hline $\mathrm{Rb}$ & 81.62 & 166 & 160 & 125 & 100 & 56.95 & 108 & 98.52 & 138 & 136 & 111 \\
\hline $\mathrm{Sr}$ & 327 & 167 & 196 & 194 & 213 & 422 & 289 & 316 & 222 & 278 & 228 \\
\hline $\mathrm{Cs}$ & 1.53 & 6.83 & 6.74 & 3.69 & 4.73 & 0.64 & 0.98 & 2.10 & 3.95 & 2.06 & 3.17 \\
\hline $\mathrm{Ba}$ & 351 & 256 & 259 & 400 & 589 & 358 & 474 & 485 & 718 & 819 & 762 \\
\hline $\mathrm{Ta}$ & 0.64 & 0.89 & 1.84 & 0.96 & 0.71 & 1.30 & 0.79 & 0.68 & 0.58 & 0.61 & 0.48 \\
\hline $\mathrm{Nb}$ & 8.55 & 8.97 & 9.43 & 10.36 & 8.73 & 13.91 & 14.36 & 10.51 & 10.62 & 14.11 & 11.67 \\
\hline $\mathrm{Zr}$ & 354 & 232 & 211 & 122 & 120 & 168 & 337 & 360 & 174 & 508 & 216 \\
\hline Hf & 8.03 & 4.84 & 4.48 & 3.85 & 3.90 & 4.54 & 7.85 & 7.73 & 5.36 & 10.64 & 6.18 \\
\hline Th & 4.53 & 8.21 & 7.61 & 9.87 & 10.77 & 6.71 & 8.58 & 7.67 & 9.89 & 12.83 & 11.06 \\
\hline $\mathrm{U}$ & 1.30 & 1.62 & 1.81 & 2.35 & 2.73 & 1.51 & 1.37 & 1.02 & 1.86 & 1.18 & 1.55 \\
\hline $\mathrm{Y}$ & 5.12 & 8.71 & 8.17 & 13.68 & 12.56 & 19.47 & 11.87 & 7.05 & 9.28 & 13.59 & 11.69 \\
\hline $\mathrm{La}$ & 16.94 & 25.30 & 24.00 & 33.15 & 45.61 & 41.58 & 50.15 & 50.63 & 64.51 & 90.24 & 79.64 \\
\hline $\mathrm{Ce}$ & 28.22 & 42.50 & 39.98 & 57.75 & 80.47 & 81.72 & 89.92 & 91.19 & 116 & 161 & 139 \\
\hline $\operatorname{Pr}$ & 3.37 & 4.89 & 4.60 & 5.39 & 7.68 & 8.48 & 10.72 & 10.91 & 10.77 & 18.82 & 13.73 \\
\hline $\mathrm{Nd}$ & 10.07 & 14.29 & 13.37 & 18.38 & 26.42 & 31.76 & 30.61 & 31.28 & 35.08 & 53.56 & 45.31 \\
\hline $\mathrm{Sm}$ & 1.74 & 2.49 & 2.29 & 3.06 & 4.08 & 5.12 & 4.63 & 4.43 & 4.65 & 7.25 & 6.04 \\
\hline $\mathrm{Eu}$ & 0.63 & 0.43 & 0.41 & 0.40 & 0.56 & 0.88 & 0.76 & 0.77 & 0.57 & 1.10 & 0.64 \\
\hline Gd & 1.15 & 1.52 & 1.48 & 2.08 & 2.56 & 3.43 & 2.75 & 2.35 & 2.57 & 3.98 & 3.35 \\
\hline $\mathrm{Tb}$ & 0.19 & 0.27 & 0.26 & 0.33 & 0.36 & 0.53 & 0.43 & 0.32 & 0.31 & 0.56 & 0.41 \\
\hline Dy & 0.81 & 1.23 & 1.17 & 2.07 & 2.03 & 3.27 & 1.82 & 1.20 & 1.72 & 2.29 & 2.19 \\
\hline Ho & 0.13 & 0.21 & 0.20 & 0.38 & 0.36 & 0.57 & 0.29 & 0.19 & 0.30 & 0.35 & 0.37 \\
\hline $\mathrm{Er}$ & 0.38 & 0.61 & 0.57 & 1.04 & 0.96 & 1.48 & 0.82 & 0.50 & 0.77 & 0.97 & 0.93 \\
\hline $\mathrm{Tm}$ & 0.06 & 0.10 & 0.09 & 0.15 & 0.14 & 0.20 & 0.12 & 0.07 & 0.10 & 0.14 & 0.12 \\
\hline $\mathrm{Yb}$ & 0.41 & 0.68 & 0.62 & 1.13 & 1.00 & 1.42 & 0.83 & 0.45 & 0.73 & 0.92 & 0.81 \\
\hline $\mathrm{Lu}$ & 0.07 & 0.11 & 0.10 & 0.20 & 0.18 & 0.23 & 0.12 & 0.07 & 0.13 & 0.14 & 0.15 \\
\hline$(\mathrm{La} / \mathrm{Yb}) \mathrm{cn}$ & 29.31 & 26.66 & 27.77 & 20.99 & 32.76 & 20.99 & 43.30 & 80.04 & 63.64 & 70.68 & 70.29 \\
\hline$(\mathrm{La} / \mathrm{Sm}) \mathrm{cn}$ & 6.30 & 6.57 & 6.77 & 7.01 & 7.22 & 5.25 & 6.99 & 7.39 & 8.97 & 8.04 & 8.52 \\
\hline$(\mathrm{Gd} / \mathrm{Yb}) \mathrm{cn}$ & 2.30 & 1.85 & 1.97 & 1.52 & 2.12 & 2.00 & 2.74 & 4.29 & 2.92 & 3.60 & 3.41 \\
\hline$(\mathrm{La} / \mathrm{Y}) \mathrm{cn}$ & 21.92 & 19.25 & 19.45 & 16.05 & 24.05 & 14.15 & 27.99 & 47.60 & 46.05 & 44.00 & 45.13 \\
\hline$\left(\mathrm{Eu} / \mathrm{Eu}^{*}\right)$ & 1.27 & 0.62 & 0.64 & 0.46 & 0.49 & 0.61 & 0.60 & 0.66 & 0.46 & 0.57 & 0.40 \\
\hline $\mathrm{Zr} / \mathrm{Hf}$ & 44.12 & 48.03 & 47.04 & 31.82 & 30.67 & 36.86 & 42.90 & 46.53 & 32.49 & 47.76 & 34.91 \\
\hline
\end{tabular}


RESEARCH ARTICLES

Table 1. (Contd)

\begin{tabular}{|c|c|c|c|c|c|c|c|c|c|c|c|}
\hline & $\begin{array}{c}\text { Non- } \\
\text { porphyritic } \\
\text { SG18-5 }\end{array}$ & $\begin{array}{c}\text { Non- } \\
\text { porphyritic } \\
\text { SG18/17 }\end{array}$ & $\begin{array}{c}\text { Non- } \\
\text { porphyritic } \\
\text { SG18/18 }\end{array}$ & $\begin{array}{c}\text { Non- } \\
\text { porphyritic } \\
\text { KDJR-18 }\end{array}$ & $\begin{array}{c}\text { Non- } \\
\text { porphyritic } \\
\text { KDJR-16 }\end{array}$ & $\begin{array}{c}\text { Porphyritic } \\
\text { KDJR-12 }\end{array}$ & $\begin{array}{c}\text { Porphyritic } \\
\text { SG18-4 }\end{array}$ & $\begin{array}{c}\text { Porphyritic } \\
\text { SG18-6 }\end{array}$ & $\begin{array}{c}\text { Porphyritic } \\
\text { KDJR-7 }\end{array}$ & $\begin{array}{c}\text { Porphyritic } \\
\text { SG18-2 }\end{array}$ & $\begin{array}{c}\text { Porphyritic } \\
\text { KDJR-1 }\end{array}$ \\
\hline $\mathrm{La} / \mathrm{Nb}$ & 1.98 & 2.82 & 2.55 & 3.20 & 5.22 & 2.99 & 3.49 & 4.81 & 6.07 & 6.39 & 6.82 \\
\hline $\mathrm{Th} / \mathrm{Nb}$ & 0.53 & 0.92 & 0.81 & 0.95 & 1.23 & 0.48 & 0.60 & 0.73 & 0.93 & 0.91 & 0.95 \\
\hline $\mathrm{Nb} / \mathrm{Ta}$ & 13.29 & 10.11 & 5.13 & 10.76 & 12.25 & 10.68 & 18.08 & 15.36 & 18.28 & 23.24 & 24.37 \\
\hline $\mathrm{Th} / \mathrm{La}$ & 0.27 & 0.32 & 0.32 & 0.30 & 0.24 & 0.16 & 0.17 & 0.15 & 0.15 & 0.14 & 0.14 \\
\hline $\mathrm{Zr} / \mathrm{Y}$ & 69.23 & 26.70 & 25.78 & 8.95 & 9.51 & 8.60 & 28.36 & 51.04 & 18.76 & 37.39 & 18.47 \\
\hline $\mathrm{Ti} / \mathrm{Zr}$ & 3.19 & 3.53 & 4.18 & 8.91 & 6.41 & 3.53 & 3.64 & 3.70 & 5.39 & 2.56 & 5.90 \\
\hline $\mathrm{Nb} / \mathrm{Nb}^{*}$ & 0.31 & 0.22 & 0.24 & 0.20 & 0.13 & 0.25 & 0.19 & 0.14 & 0.11 & 0.10 & 0.10 \\
\hline $\mathrm{Zr} / \mathrm{Zr}^{*}$ & 5.87 & 2.70 & 2.64 & 1.13 & 0.80 & 0.91 & 1.96 & 2.12 & 0.94 & 1.78 & 0.90 \\
\hline $\mathrm{Hf} / \mathrm{Hf}^{*}$ & 4.82 & 2.04 & 2.03 & 1.29 & 0.94 & 0.89 & 1.65 & 1.65 & 1.05 & 1.35 & 0.94 \\
\hline $\mathrm{Ti} / \mathrm{Ti}^{*}$ & 0.32 & 0.17 & 0.19 & 0.17 & 0.09 & 0.06 & 0.14 & 0.16 & 0.11 & 0.10 & 0.11 \\
\hline $\mathrm{Sr} / \mathrm{Y}$ & 63.87 & 19.22 & 23.99 & 14.17 & 16.93 & 21.66 & 24.32 & 44.90 & 23.97 & 20.44 & 19.49 \\
\hline
\end{tabular}
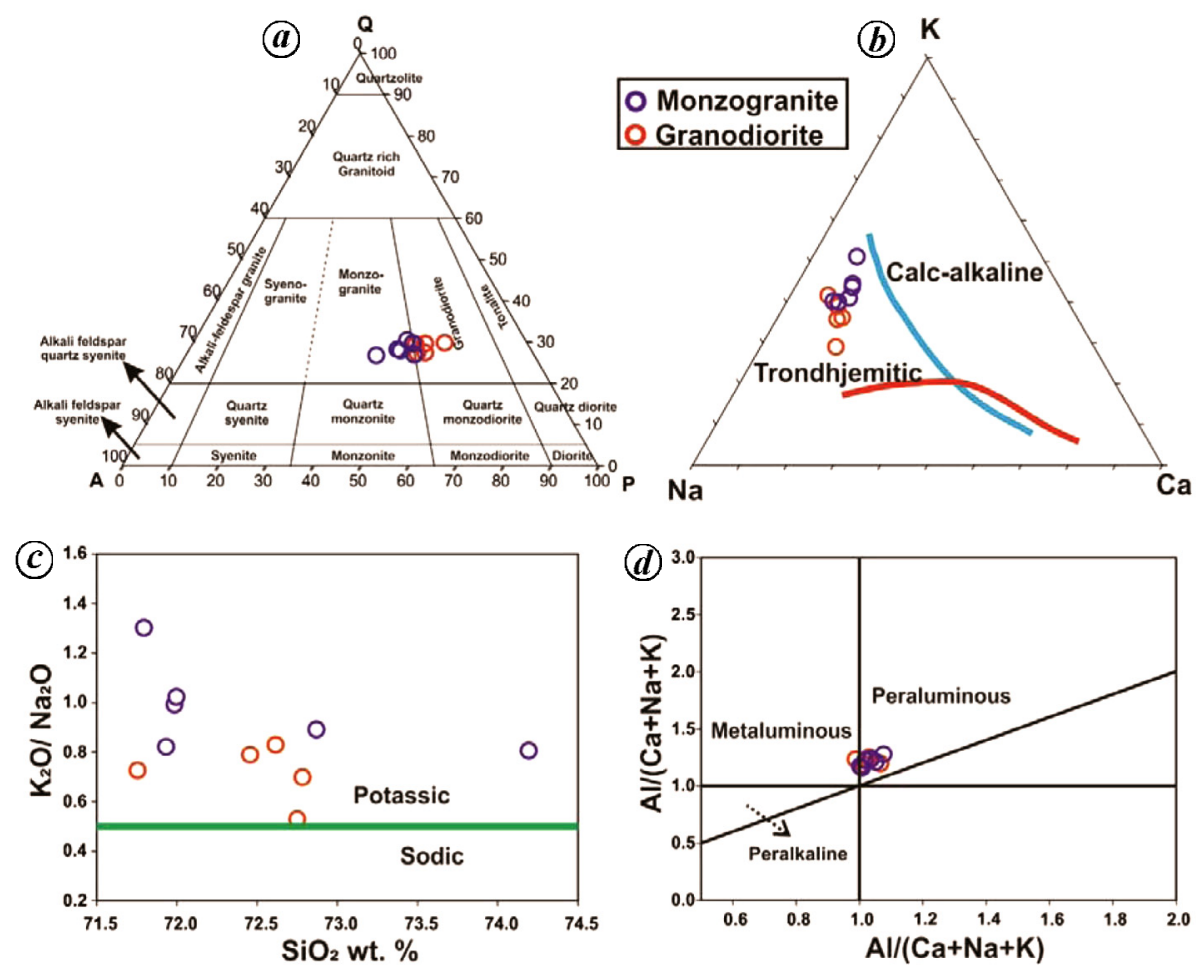

Figure 4. $\boldsymbol{a}$, Normative quartz, alkali feldspar and plagioclase content in Keonjhar granitoids. The fields are from Streckeisen ${ }^{57}$. $\boldsymbol{b}$, Ternary $\mathrm{K}-\mathrm{Ca}-\mathrm{Na}$ plot with fields from Barker ${ }^{38}$. $\boldsymbol{c}$, Potassic nature of the samples highlighted by $\mathrm{K}_{2} \mathrm{O} / \mathrm{Na}_{2} \mathrm{O}$ plot. $\boldsymbol{d}$, Alumina saturation index, after Shand ${ }^{37}$. Blue circles represent monzogranite and red circles represent granodiorite samples.

with LILE-enriched, flat HREE pattern with anomalies of $\mathrm{Sr}, \mathrm{Nb}, \mathrm{Ta}, \mathrm{Pb}$ and $\mathrm{Ti}$, which are the conventional features of rocks formed in convergent margin settings. However, these anomalies alone cannot help infer the subduction environment for the evolution of Archean granitoids, but can also define the crustal signatures ${ }^{43}$ and/or mineral fractionation. In addition, a plume that has interacted with the continental crust or lithosphere can also form basalts with similar geochemical patterns to those of arc derived ${ }^{44}$. Generation of calc-alkaline felsic crust with arc-like geochemical systematics, formed due to partial melting of basaltic crust under high-pressure conditions below mafic plateaus has also been validated ${ }^{45}$.

Fractionated REE patterns with flat HREE and negative $\mathrm{Eu}$ anomalies suggest shallow melting conditions, where plagioclase is in the source residue (Figure $5 a$ ). Lower $\mathrm{Sr}$ concentrations and $\mathrm{Sr} / \mathrm{Y}<40$ (Table 1) imply low-pressure melting conditions, and confer the above inference. The low Sr/Y ratios could actually result from intracrustal melting below a thickened crust or oceanic 

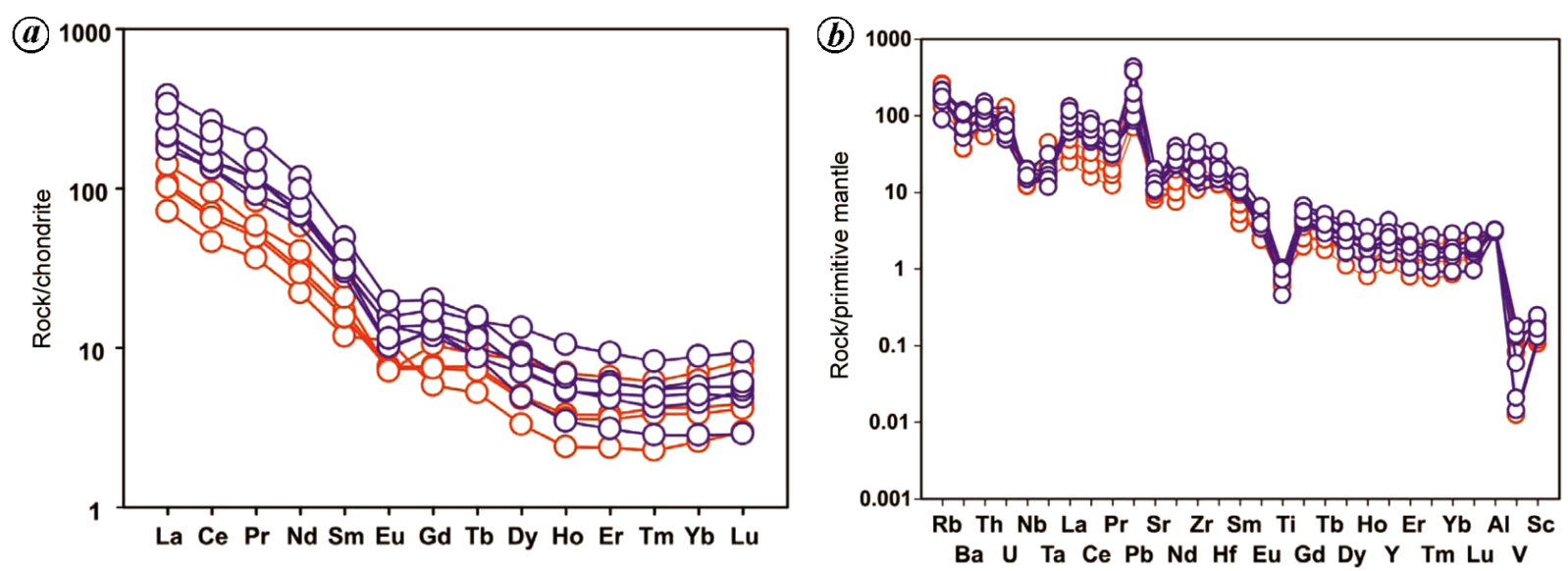

Figure 5. $\boldsymbol{a}$, Chondrite normalized REE plot. $\boldsymbol{b}$, Primitive mantle normalized multielemental variation diagrams for Keonjhar granitoids. Normalized values are from Sun and $\mathrm{Mcdonough}^{40}$. Blue circles represent monozogranite and red circles represent granodiorite samples.
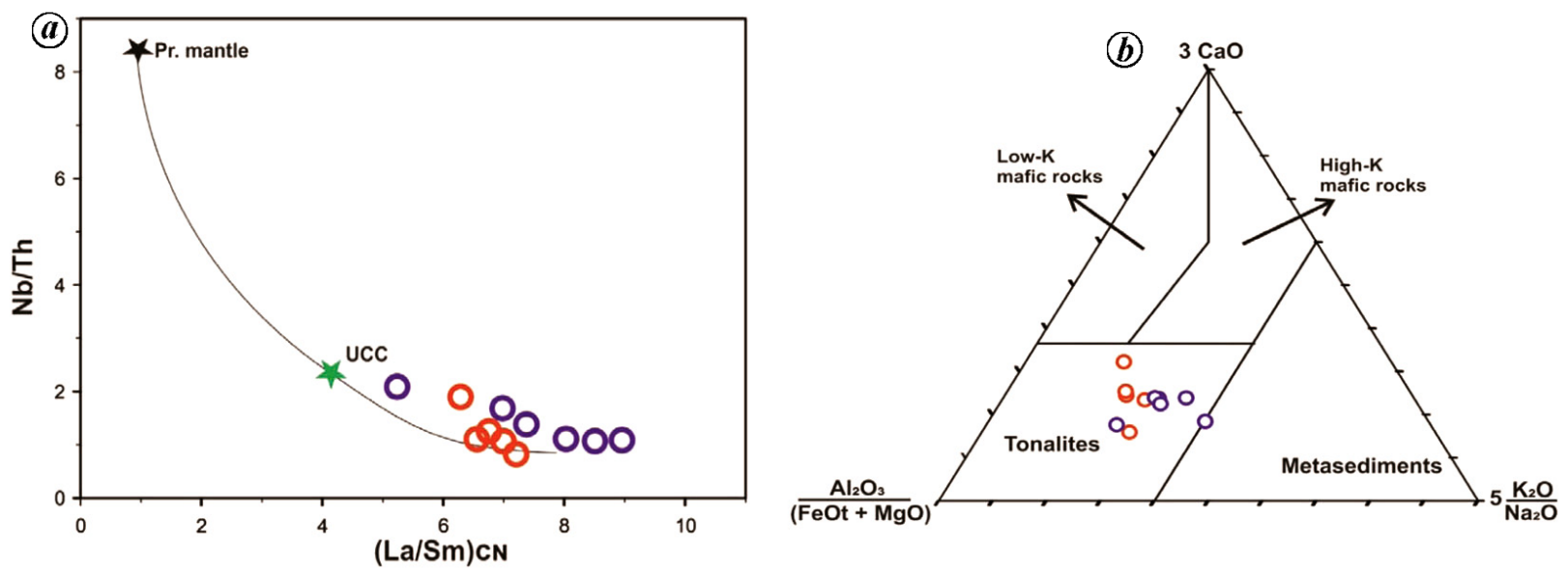

Figure 6. $\boldsymbol{a},(\mathrm{La} / \mathrm{Sm})_{\mathrm{N}}$ versus $\mathrm{Nb} / \mathrm{Th}$ plot showing nature of the source involved in the petrogenesis of Keonjhar granitoids. $\boldsymbol{b}$, Ternary plot showing potential source(s) involved in the petrogenesis of Archean granitoids ${ }^{17}$. Blue circles represent monozogranite and red circles represent granodiorite samples.

plateau $^{46}$. In oceanic plateau environments, multiple melting episodes due to plume underplating, intracrustal melting of the basalts and their differentiated products result in the genesis of potassic granites ${ }^{16}$. The low concentrations of transition elements eliminates the possibility of any mantle-wedge interactions. Disposition of Keonjhar granitoids proximal to the upper continental crust in the $(\mathrm{La} / \mathrm{Sm})_{\mathrm{N}}$ versus $(\mathrm{Th} / \mathrm{Nb})_{\mathrm{N}}$ plot suggest infracrustal melting (Figure $6 a$ ). In the ternary source discrimination diagram $^{17}$, these rocks are distributed into the tonalitic field, implying that partial melting of OMTG tonalities is responsible for the evolution of Keonjhar granitoids (Figure $6 b)^{26}$.

\section{Geodynamic implications: vertical or horizontal tectonics in Palaeoarchean Singhbhum Craton?}

The Keonjhar pluton was earlier considered as TTG-like, with depleted mantle-like $\varepsilon \mathrm{Nd}_{\mathrm{t}}$ values ${ }^{29}$. In contrast, zir- cons from the Keonjhar granitoids also have positive $\varepsilon \mathrm{Hf}_{\mathrm{t}}$ $(+1.8$ to 4.0$)$ values $^{26}$, suggesting that these magmas are evolved with enriched mantle signature. Hence, the Keonjhar suite can be better explained as the product of intracrustal melting of the OMTG at different depths. On the other hand, zircons from the OMTG rocks ${ }^{30}$ and $\mathrm{SG}^{26}$ display Hf isotope signatures of an initially enriched mantle source with variable $\varepsilon \mathrm{Hf}_{\mathrm{t}}$ values, to suggest subsequent multiple crustal reworking events. Such variability in isotopic systematics with an initial enriched mantle source, followed by variably evolved signatures can be explained in an oceanic plateau environment, followed by differentiation at various crustal levels ${ }^{47}$. In the case of the Singhbhum Craton, this scenario can be extrapolated in two stages; the first stage to correlate with the formation of the $\mathrm{OMTG}^{26}$, derived due to the melting of (plumederived) enriched basaltic source at the base of an oceanic plateau. In the second stage, the resultant underplating at crustal levels caused the reworking that lead to intracrustal 
melting and differentiation of the OMTG to form potassic granites, similar to that of the Keonjhar pluton.

The origin of supracrustals and evolution of the Singhbhum Craton are a matter of contention. Boninitelike affinity of the OMG rocks was reported and interpreted to have formed by intra-oceanic subduction ${ }^{48}$. The petrogenesis of southern IOG basin containing ultramafics, basalt and dacite has been attributed to subduction environment ${ }^{24,49}$. Earlier works have shown that basic rocks of the IOG basin have both tholeiitic as well as calc-alkaline affinity ${ }^{50}$. The komatiies from the northeast Gorumahisani-Badampahar basin show geochemical signatures of a plume emplaced on the ocean floor ${ }^{51}$.

Five-stage evolutionary model for the Singhbhum Craton has been proposed based on deformational features, depositional ages of the IOG sediments and emplacement of granitoid magmatism, and the corresponding metamorphism is attributed to crustal upliftment and exten$\operatorname{sion}^{25}$. This model does not favour subduction-like mechanism for growth of the craton. The role of mantle underplating below an oceanic plateau is supported by the occurrences of partial convective overturns (PCOs) elsewhere $^{52,53}$. A two-stage PCO model based on field observations and microstructures in OMG, OMTG, IOG and $\mathrm{SG}$ has been proposed ${ }^{54}$. Dome and keel structures in the Eastern Pilbara Craton formed as the result of cyclic gravitational overturns due to Rayleigh Taylor instability (RTI) arising at the boundary between the mafic and felsic magmas ${ }^{13}$. Further, it has been proposed that RTI occurs at a gap of 100 myr and is common in most of the $>3.0 \mathrm{Ga}$ cratons $^{53}$. Considering the similarities in emplacement ages of both cratons, their geometry and geochemical composition of granitoids, we can infer the occurrence of at least two RTI cycles in the Singhbhum Craton, wherein the first RTI cycle corresponds to TTG magmatism at $\sim 3.45-3.44 \mathrm{Ga}$, and the second cycle coincides with SG emplacement at $\sim 3.35-3.32 \mathrm{Ga}$, roughly with $\sim 100$ Ma pause.

The available geophysical studies report a crustal thickness of $\sim 46 \mathrm{~km}$ for the Palaeoarchean crust of Singhbhum Craton and the subsurface structure is linked to plume activity ${ }^{55,56}$. Teleseismic data were used to obtain an average crustal thickness of $\sim 43 \mathrm{~km}$ for the Singhbhum Craton; the thickness varied from as high as $\sim 46 \mathrm{~km}$ below the Palaeoarchean Singhbhum Craton to $\sim 38 \mathrm{~km}$ below the Eastern Ghats Mobile Belt ${ }^{55}$. A very low conductivity of Continental Lower Crust $(\sim 0.00012 \mathrm{~S} / \mathrm{m})$ was obtained below the craton, comparable to that observed in Pilbara; this is due to the absence of subducting slab and the associated down-going sediments. The layered structures are an outcome of mantle plume activity $^{56}$. These observations suggest that the Singhbhum Craton closely resembles the Eastern Pilbara Craton with respect to geometry, occurrence of dome and keel structured granites, periphery bounding greenstone belts apart from subsurface features as outlined above.
In this study, apart from geochemical data, we rely on craton-scale field geometry and lithological associations, along with available geochemical, isotopic systematics and geophysical observations to propose that the generation of continental crust of the Singhbhum Craton is the product of vertical tectonics. Evidences are drawn for the resemblance of Keonjhar granites to granites reported from the Eastern Pilbara Craton. However, there is a need to reconsider the major Palaeoarchean lithounits (OMTG and IOG) with the aid of precise geochronological and isotopic systematics for a comprehensive understanding of the Palaeo to Mesoarchean geodynamics, for better clarity on the evolution of the Singhbhum Craton.

\section{Conclusion}

The Keonjhar suite is made of monzogranites and granodiorites related by different degrees of differentiation. Compositionally, they are not TTGs, but are the product of TTG melting. The petrogenesis of Keonjhar granites can be explained as the product of intracrustal melting of an older TTG (OMTG) in an oceanic plateau setting.

1. Dhuime, B., Hawkesworth, C. J., Cawood, P. A. and Storey, C. D., A change in the geodynamics of continental growth 3 billion years ago. Science, 2012, 335, 1334-1336.

2. Belousova, E., Kostitsyn, Y., Griffin, W. L., Begg, G. C., O'Reilly, S. Y. and Pearson, N. J., The growth of the continental crust: constraints from zircon Hf-isotope data. Lithos, 2010, 119 , 457-466.

3. Polat, A., Hofmann, A. and Rosing, M. T., Boninite-like volcanic rocks in the 3.7-3.8 Ga Isua greenstone belt, west Greenland: geochemical evidence for intra-oceanic subduction zone processes in the early earth. Chem. Geol., 2002, 184, 231-254.

4. Komiya, T., Maruyama, S., Masuda, T., Nohda, S., Hayashi, M. and Okamoto, K., Plate tectonics at 3.8-3.7 Ga: field evidence from the Isua accretionary complex, southern west Greenland. $J$. Geol., 1999, 107, 515-554.

5. Nutman, A. P. and Collerson, K. D., Very early Archean crustalaccretion complexes preserved in the north Atlantic craton. Geology, 1991, 19, 791-794.

6. Shirey, S. B. and Richardson, S. H., Start of the Wilson cycle at $3 \mathrm{Ga}$ shown by diamonds from subcontinental mantle. Science, 2011, 333, 434-436.

7. Condie, K. C. and Kröner, A., When did plate tectonics begin? Evidence from the geologic record. In Special Paper of the Geological Society of America (eds Condie, K. C. and Pease, V.), 2008, pp. 281-294.

8. Moyen, J. F., Stevens, G. and Kisters, A., Record of mid-archaean subduction from metamorphism in the Barberton terrain, South Africa. Nature, 2006, 442, 559-562.

9. Smithies, R. H., Champion, D. C., Van Kranendonk, M. J., Howard, H. M. and Hickman, A. H., Modern-style subduction processes in the Mesoarchean: geochemical evidence from the $3.12 \mathrm{Ga}$ Whundo intra-oceanic arc. Earth Planet. Sci. Lett., 2005, 231, 221-237.

10. Hawkesworth, C., Cawood, P., Kemp, T., Storey, C. and Dhuime, B., Geochemistry: a matter of preservation. Science, 2009, 323, 49-50.

11. Scholl, D. W. and von Huene, R., Crustal recycling at modern subduction zones applied to the past - issues of growth and pre- 
servation of continental basement crust, mantle geochemistry, and supercontinent reconstruction. Geol. Soc. America Mem., 2007, 200, 9-32.

12. Condie, K. C., Mantle Plumes and their Record in Earth History, Cambridge University Press, Cambridge, UK, 2001, pp. 170246 .

13. Van Kranendonk, M. J., Hugh Smithies, R., Hickman, A. H. and Champion, D. C., Review: secular tectonic evolution of archean continental crust: interplay between horizontal and vertical processes in the formation of the Pilbara Craton, Australia. Terra Nova, 2007, 19, 1-38.

14. Smithies, R. H., Champion, D. C. and Van Kranendonk, M. J., Formation of Paleoarchean continental crust through infracrustal melting of enriched basalt. Earth Planet. Sci. Lett., 2009, 281, 298-306.

15. Bédard, J. H., Stagnant lids and mantle overturns: implications for Archaean tectonics, magmagenesis, crustal growth, mantle evolution, and the start of plate tectonics. Geosci. Frontiers, 2018, 9 19-49.

16. Van Kranendonk, M. J., Two types of Archean continental crust: plume and plate tectonics on early earth. Am. J. Sci., 2010, 310, 1187-1209.

17. Laurent, O., Martin, H., Moyen, J. F. and Doucelance, R., The diversity and evolution of late-Archean granitoids: evidence for the onset of 'modern-style' plate tectonics between 3.0 and $2.5 \mathrm{Ga}$. Lithos, 2014, 205, 208-235.

18. Kamber, B. S., The evolving nature of terrestrial crust from the Hadean, through the Archaean, into the Proterozoic. Precambrian Res., 2015, 258, 48-82.

19. Saha, A. K., M-27. Crustal evolution of Singhbhum - North Orissa, Eastern India, Memoir, Geological Society of India, Bangalore, India, 1994, vol. 27, pp. 1-341.

20. Mukhopadhyay, D., The Archaean nucleus of Singhbhum: the present state of knowledge. Gondwana Res., 2001, 4, 307-318.

21. Goswami, J. N., Mishra, S., Wiedenbeck, M., Ray, S. L. and Saha, A. K., 3.55 Ga old zircon from Singhbhum-Orissa Iron Ire Craton, eastern India. Curr. Sci., 1995, 69, 1008-1011.

22. Hofmann, A. and Mazumder, R., A review of the current status of the older metamorphic group and older metamorphic tonalite gneiss: insights into the Palaeoarchaean history of the Singhbhum Craton, India. Geol. Soc., London, Mem., 2015, 43, 103-107.

23. Mukhopadhyay, J., Beukes, N. J., Armstrong, R. A., Zimmermann, U., Ghosh, G. and Medda, R. A., Dating the oldest greenstone in India: a 3.51-Ga precise $\mathrm{U}-\mathrm{Pb}$ shrimp zircon age for dacitic lava of the southern iron ore group, Singhbhum Craton. J. Geol., 2008, 116, 449-461.

24. Mukhopadhyay, J., Ghosh, G., Zimmermann, U., Guha, S. and Mukherjee, T., A 3.51 Ga bimodal volcanics-BIF-ultramafic succession from Singhbhum Craton: implications for Palaeoarchaean geodynamic processes from the oldest greenstone succession of the Indian subcontinent. Geochem. J., 2012, 47, 284-311.

25. Nelson, D. R., Bhattacharya, H. N., Thern, E. R. and Altermann, $\mathrm{W}$., Geochemical and ion-microprobe $\mathrm{U}-\mathrm{Pb}$ zircon constraints on the Archaean evolution of Singhbhum Craton, eastern India. Precambrian Res., 2014, 255, 412-432.

26. Dey, S., Topno, A., Liu, Y. and Zong, K., Generation and evolution of Paleoarchean continental crust in the central part of the Singhbhum Craton, eastern India. Precambrian Res., 2017, 298, 268-291.

27. Upadhyay, D., Chattopadhyay, S., Kooijman, E., Mezger, K. and Berndt, J., Magmatic and metamorphic history of paleoarchean tonalite-trondhjemite-granodiorite (TTG) suite from the Singhbhum Craton, eastern India. Precambrian Res., 2014, 252, 180-190.

28. Acharyya, S. K., Gupta, A. and Orihashi, Y., New U-Pb zircon ages from paleo-mesoarchean ttg gneisses of the Singhbhum Craton, eastern India. Geochem. J., 2010, 44, 81-88.
29. Tait, J., Zimmermann, U., Miyazaki, T., Presnyakov, S., Chang, Q., Mukhopadhyay, J. and Sergeev, S., Possible juvenile palaeoarchaean TTG magmatism in eastern India and its constraints for the evolution of the Singhbhum Craton. Geol. Mag., 2011, 148, 340-347.

30. Chaudhuri, T., Wan, Y., Mazumder, R., Ma, M. and Liu, D., Evidence of enriched, Hadean mantle reservoir from 4.2-4.0 Ga zircon xenocrysts from Paleoarchean TTGs of the Singhbhum Craton, eastern India. Sci. Rep., 2018, 8, 7069.

31. Miller, S. R., Mueller, P. A., Meert, J. G., Kamenov, G. D., Pivarunas, A. F., Sinha, A. K. and Pandit, M. K., Detrital zircons reveal evidence of Hadean crust in the Singhbhum Craton, India. J. Geol., 2018, 126, 541-552.

32. Kumar, A., Parashuramulu, V., Shankar, R. and Besse, J., Evidence for a Neoarchean lip in the Singhbhum Craton, eastern India: implications to Vaalbara supercontinent. Precambrian Res., 2017, 292, 163-174.

33. Shankar, R., Vijayagopal, B. and Kumar, A., Precise $\mathrm{Pb}-\mathrm{Pb}$ baddeleyite ages of $1765 \mathrm{Ma}$ for a Singhbhum 'newer dolerite' dyke swarm. Curr. Sci., 2014, 106, 1306-1310.

34. Krishna, A., Murthy, N. and Govil, P., Multielement analysis of soils by wavelength-dispersive X-ray fluorescence spectrometry. At. Spectrosc.-Norwalk Connecticut, 2007, 28, 202.

35. Satyanarayanan, M., Balaram, V., Sawant, S., Subramanyam, K., Krishna, G. V., Dasaram, B. and Manikyamba, C., Rapid determination of REEs, PGEs, and other trace elements in geological and environmental materials by high resolution inductively coupled plasma mass spectrometry. At. Spectrosc., 2018, 39, 1-15.

36. Páez, G., Ruiz, R., Guido, D., Jovic, S. and Schalamuk, I., The effects of K-metasomatism in the Bahía Laura volcanic complex, Deseado massif, Argentina: petrologic and metallogenic consequences. Chem. Geol., 2010, 273, 300-313.

37. Shand, S. J., Eruptive Rocks, Thomas Murphy, 1947, p. 444.

38. Barker, F., Trondhjemite: definition, environment and hypotheses of origin. In Developments in Petrology (ed. Barker, F.), Elsevier, 1979, pp. 1-12.

39. Rapp, R. P., Shimizu, N., Norman, M. and Applegate, G., Reaction between slab-derived melts and peridotite in the mantle wedge: experimental constraints at $3.8 \mathrm{GPa}$. Chem. Geol., 1999, 160, 335-356.

40. Sun, S. S. and McDonough, W. F., Chemical and isotopic systematics of oceanic basalts: Implications for mantle composition and processes. In Magmatism in Ocean Basins (eds Saunders, A. D. and Norry, M. J.), Geological Society of London, UK, 1989, vol. 42, pp. 313-345

41. Bickle, M. J., Bettenay, L. F., Chapman, H. J., Groves, D. I., McNaughton, N. J., Campbell, I. H. and de Laeter, J. R., Origin of the 3500-3300 Ma calc-alkaline rocks in the Pilbara Archaean: isotopic and geochemical constraints from the Shaw batholith. Precambrian Res., 1993, 60, 117-149.

42. Champion, D. C. and Smithies, R. H., Geochemistry of Paleoarchean granites of the east Pilbara terrane, Pilbara Craton, Western Australia: implications for early Archean crustal growth. In Earth's Oldest Rocks (eds Van Kranendonk, M. J., Hugh Smithies, R. and Bennett, V. C.), Developments in Precambrian Geology, Elsevier, 2008, vol. 15, pp. 369-409.

43. Rudnick, R. L. and Fountain, D. M., Nature and composition of the continental crust: a lower crustal perspective. Rev. Geophys., 1995, 33, 267-309.

44. Condie, K. C., High field strength element ratios in Archean basalts: a window to evolving sources of mantle plumes? Lithos, 2005, 79, 491-504.

45. Willbold, M., Hegner, E., Stracke, A. and Rocholl, A., Continental geochemical signatures in Dacites from Iceland and implications for models of early Archaean crust formation. Earth Planet. Sci. Lett., 2009, 279, 44-52.

46. Moyen, J.-F., High $\mathrm{Sr} / \mathrm{Y}$ and $\mathrm{La} / \mathrm{Yb}$ ratios: the meaning of the 'adakitic signature'. Lithos, 2009, 112, 556-574. 
47. Gardiner, N. J., Hickman, A. H., Kirkland, C. L., Lu, Y., Johnson, T. and Zhao, J.-X., Processes of crust formation in the early earth imaged through Hf isotopes from the East Pilbara terrane. Precambrian Res., 2017, 297, 56-76.

48. Manikyamba, C., Ray, J., Ganguly, S., Singh, M. R., Santosh, M., Saha, A. and Satyanarayanan, M., Boninitic metavolcanic rocks and island arc tholeiites from the older metamorphic group (OMG) of Singhbhum Craton, eastern India: geochemical evidence for Archean subduction processes. Precambrian Res., 2015, 271, 138159.

49. Mukhopadhyay, J., Beukes, N., Armstrong, R., Zimmermann, U., Ghosh, G. and Medda, R., Dating the oldest greenstone in India: a $3.51 \mathrm{Ga}$ precise $\mathrm{U}-\mathrm{Pb}$ shrimp zircon age for dacitic lava of the southern iron ore group, Singhbhum Craton. J. Geol., 2008, 116, 449-461.

50. Sengupta, S., Acharyya, S. and DeSmeth, J., Geochemistry of Archaean volcanic rocks from iron ore supergroup, Singhbhum, eastern India. Proc. Indian Acad. Sci. - Earth Planet. Sci., 1997, 106, 327.

51. Chaudhuri, T., Mazumder, R. and Arima, M., Petrography and geochemistry of Mesoarchean komatiites from the eastern iron ore belt, Singhbhum Craton, India, and its similarity with 'barberton type komatiite'. J. Afr. Earth Sci., 2015, 101, 135-147.

52. Collins, W. J., Van Kranendonk, M. J. and Teyssier, C., Partial convective overturn of Archaean crust in the east Pilbara Craton, western Australia: driving mechanisms and tectonic implications. J. Struct. Geol., 1998, 20, 1405-1424.
53. Wiemer, D., Schrank, C. E., Murphy, D. T., Wenham, L. and Allen, C. M., Earth's oldest stable crust in the Pilbara Craton formed by cyclic gravitational overturns. Nature Geosci., 2018, 11, 357-361.

54. Prabhakar, N. and Bhattacharya, A., Paleoarchean partial convective overturn in the Singhbhum Craton, eastern India. Precambrian Res., 2013, 231, 106-121.

55. Mandal, P. and Biswas, K., Teleseismic receiver functions modeling of the eastern Indian Craton. Phys. Earth Planet. Inter., 2016, 258, $1-14$.

56. Bhattacharya, B. B., The electric moho underneath eastern Indian Craton. Geophys. Res. Lett., 2002, 29, 14-1-14-4.

57. Streckeisen, A., To each plutonic rock its proper name. Earth Sci. Rev., 1976, 12, 1-33.

ACKNOWLEDGEMENTS. We thank the Director, CSIR-National Geophysical Research Institute for the permission to publish the results. This work is an outcome of the GEOMET project, and is part of the Ph D work of the Ajay Dev. Ajay Dev is supported by University Grants Commission-Junior Research Fellowship. We thank the Dr M. Satyanarayanan and Dr A. Keshav Krishna for acquisition of trace and major elements data respectively. Critical comments from an anonymous reviewer helped improve the manuscript.

Received 13 November 2018; revised accepted 14 November 2019 doi: $10.18520 / \mathrm{cs} / \mathrm{v} 118 / \mathrm{i} 6 / 910-919$ 